\title{
ON THE FOOD OF YOUNG FISHES.
}

\author{
BY S. A. FORBES.
}

I cannot learn that anything has been recorded respecting the food of young fishes in this country, nor have I been able to find anything upon this subject in such part of the ichthyological literature of Europe as is accessible to me. From the lack of all mention of the use of Entomostraca as the food of young fishes in the general review of the relations of these Crustacea to organic nature given by Gerstaecker in Bronn's ThierReich + I infer that whatever systematic investigation the subject may have received, the results have not attracted any general attention.

This seems a surprising fact when one considers the vast amount of labor which has been expended upon this class of animals, and reflects for a moment upon the interest to science and to practical fish-culture of a knowledge of the food resources of fishes and of the competitions of the various species in the search for subsistence.

Although I cannot yet treat this subject as fully as it deserves, the results of such study as I have been able to make, during the past season, of the contents of the stomachs and intestines of small specimens, seem to justify this preliminary notice.

It was early apparent, in the course of the investigation, that the food of many fishes differs greatly according to age ; and it was soon found that the life of most of our fishes divides into at least two periods, and of many into three, with respect to the kinds of food chiefly taken. Further, in the first of these periods a remarkable similarity of food was noticed among species and families whose later food-habits are widely different.

* Perhaps exception should be made of a note relating to the occurrence of diatoms in the stomachs of two young whitefishes, published in the appendix to the Report of the U. S. Fish Commissioner for 1872-3, p. 57.

† Classen und Ordnungen des Thier-Reichs, Band V, Ahtheilung 1, ss. 750 u. 1057. 
The full-grown black bass, for example, feeds principally on fishes and crawfishes, the sheepshead on mollusks, the gizzard-shad on mud and Algæ, while the catfishes are nearly onınivorous; yet these are all found to agree so closely in food when very small that one could not possibly tell from the contents of the stomachs which group he was dealing with.

It is my purpose in this paper to give what facts $I$ have relating to the food of our fresh-water species during this first period of the fish's life. These facts were derived from the examination of one hundred and twentysix specimens, ranging from three-eighths of an inch in length up to an inch and a half, and in a few cases to two and three inches. These specimens belong to twenty-four genera and represent eleven families. In two or three genera none were obtained small enough to be regarded as belonging strictly to this first food-period, but the earliest food is nevertheless plainly inferable; and the general distribution and variety of the species studied is such that I think the main conclusions will be found to stand the test of full investigation. As the first period is evidently much shorter with some species than with others, and doubtless varies in the same species according to situation and circumstances generally, of course no common limit of size could be set up, but the smallest specimens of each species were selected until a size was reached where a marked difference of food appeared.

\section{Acanthopteri.}

Although the young Acanthopteri have already been discussed in the preceding paper on the food of that group, it will be convenient to review the facts concerning these young fishes for the purpose of comparing their food with that of the other orders.

The food of six common perch (Perca americana), from an inch to an inch and a quarter long, consisted wholly of Entomostraca and larvæ of Chironomus - eight per cent. Chironomus, fifty-two per cent. Cladocera and forty per cent. Copepoda. 
No very small Labracidæ were found, the youngest being a Morone an inch and a quarter long. Half of the food of this consisted of Entomostraca (chiefly Cladocera), and the other half was minute gizzard-shad.

A group of forty-three sunfishes (Centrarchidæ), from five-eighths of an inch to two inches long, was made up as follows:- of five specimens of Micropterus under three-fourths of an inch long, two Ambloplites of the same size, two of Chænobryttus from seven-eighths of an inch to one inch, one of Apomotis an inch in length, nine of Lepiopomus from an inch to an inch and a fourth, nine of Eupomotis from one and a half to two inches, five of Centrarchus one inch and under, four of Pomoxys from three-fourths of an inch to an inch and a half, and six indeterminable specimens, probably Lepiopomus, from seven-sixteenths to five-eighths of an inch long. Ninetysix per cent. of the food of these forty-three specimens consisted of Entomostraca and larvæ of Chironomusseventy of the first and twenty-six of the second-the trivial remainder consisting of Neuroptera larvæ and young Amphipoda with traces of water mites, Corixas and mollusks (the last in Eupomotis). The Entomostraca were forty-two per cent. Cladocera, nineteen per cent. Copepoda and nine per cent. Ostracoda.

A single Haploidonotus an inch and an eighth in length, had eaten Chironomus larvæ (seventy-five per cent.) and larvæ of Palingenia bilineata.

\section{Esocide.}

I did not have the good fortune to obtain any young of the common pike, and can only report on the food of a single Esox salmoneus an inch and a fourth in length. This specimen, taken at Pekin, Ill., on the $2 d$ of June, had already begun its life labor of the elimination of little fishes, these making about two-fifths of its food. The remainder consisted of Crustacea, composed about equally of young Amphipoda, Daphniidx and Lynceidæ. The presence of so large a quantity of these minute Entomostraca in the stomach of a pickerel of this size, is sufficient evidence that they form the principal part of its food at an earlier age. 


\section{Clupeide.}

We come next to twelve specimens of the gizzard-shad (Dorysoma), whose minute fry swarm in countless numbers in the waters of our larger rivers in midsummer. These were taken in June and July, from the Illinois R., from Ottawa to Peoria. The smallest of the group were twenty $\mathrm{mm}$. long by two $\mathrm{mm}$. wide - as slender as cyprinoids and nearly cylindrical, although the adult is a high, thin fish. I was greatly interested by the discovery that the maxillaries of these smallest specimens are provided with teeth-a single row of nine or ten on the lower edge - although the mouth of the adult is entirely toothless and smooth. The internal structure also differs rentarkably from that of the adult, especially in the much greater simplicity of the digestive apparatus. In a young gizzard-shad seven-tenths of an inch long by one-tenth high, the intestine was found to pass from the anterior end of the stomach to the vent with only one short forward turn of about a fourth the length of the body cavity, made a little way behind the stomach. Although the mucous surface of the intestine was at this time very rugose, showing a commencing complication of the digestive system, there was no trace of pyloric coca. The intestine was filled with Cypris, Chydorus, Alona, Cyclops, etc.

On the other hand, in a fish three and three-fourths inches long, showing the general characters of the adult, the intestine passed upward and backward from its origin, running without flexure the whole length of the body cavity (this part being covered with an immense number of pyloric cocea), then turned forward to the stomach, ran back from there about one-third of the way to the vent, then turned forward and ran a tortuous course beneath the stomach to the pericardial membrane and back again, also tortuously, two-thirds of the way to the vent. From this point it ran forward again to the stomach, and crossing to the left side, ran repeatedly backward and forward in the posterior part of the body eavity, making seven turns between the stomach and vent before opening, thus extending, in all, about eight times the length of the perivisceral cavity. This intestine was 
well filled with mud with only a slight sprinkling of unicellular Algæ.

Much as these young resemble young Cyprinidæ, they ean be easily distinguished from them by the very long anal fin; and from the brook silversides (Labidesthes), to which they bear some superficial resemblance, by the absence of a spinous dorsal.

These twelve fishes, all under two inches in length, had eaten about ninety per cent. of Entomostraca, two per cent. of Chironomus larvæ, and for the remainder, Algæ. The Crustacea were about equally Cladocera and Copepoda. Among the former were Daphnia pulex,-Simocephalus americanus, Ceriodaphnia dentata, Bosmina, Chydorus and Alona. In a specimen three-quarters of an inch long which I took from the stomach of a Morone interrupta, I found a few specimens of Leptodora hyalina (?) Lillj. The Copepoda were all Cyclops, so far as recognizable.

\section{CyPRINIDE.}

A single minute minnow, three-eighths of an inch long, which I could not determine specifically, had eaten Daphnids (twenty-five per cent.) and Chironomus larvæ..

The specimens of the common chub minnow (Semotilus corporalis), ranging from five-eighths inch to one inch, indicate somewhat doubtfully an exception to the general rule respecting the early food of fishes. Only seven per cent. of their food was Entomostraca, and the whole remainder consisted of filamentous Algæ. It should be noted, however, that twenty per cent. of the food of the smallest specimen, which was five-eighths of an inch long, was Cyclops, and it may be that Semotilus lives wholly on Entomostraca at first, merely changing its habit earlier than most of its allies.

Two specimens of Notropis, an inch and a half in length had eaten nothing but Daphnids.

\section{Catostomide.}

Thirty specimens, representing five genera of this peculiar family, were studied. A very curious feature of the food of the young is the frequent dependence of suckers 
of considerable size-six inches long or more-upon food more trivial than Copepoda or Lynceidæ; viz., upon rotifers, Protozoa and unicellular Algæ. While only such Protozoa were found as are furnished with firm tests or carapaces, yet the abundance of Difflugia and Arcella in the intestines of these fishes leaves little doubt that the more perishable Protozoa must also be taken in considerable quantity. It is an interesting fact that even here the smallest specimens were found feeding on Entomostraca only, and it is therefore possible that these form the first food of the family.

Ten specimens of the stone-roller (Hypentelium nigricans), ranging from one and three-eighths to three inches represent two dates and localities. The four smallest, none larger than an inch and three-fourths, were taken from the lower Fox, July 9, 1879. The others were obtained from Mackinaw Cr., in Woodford Co., Ill., in the latter part of August. The situations were similar, both streams being swift and rocky where these fishes were caught. Their food was chiefly the larvæ of Chironomus (ninety per cent.), the remaining tenth being principally made up of Alona (six per cent.). Ostracoda, Copepoda, and Algre each made about one per cent. of the food. The Algæ were mostly diatoms and desmids, Closterium being especially common. Many Difflugia and Arcella were also found in these fishes.

We trace in this a remarkable resemblance to the food of the darters, which, it will be remembered, frequent similar situations. Lacking the sucking mouth of Hypentelium, they do not take Protozoa or unicellular Algæ, but in other particulars agree closely with this species. This curious fish is peculiar among the suckers in the unusual development of the pectoral fins - a distinguishing feature of the darters likewise-doubtless related, in both cases, to the constant struggle with a swift current. We may also remark the darter-like glow of color in the young of this species-a very peculiar distinction among: the Catostomidæ. This is one among many facts which indicate that exposure to light has great primary effect on the color of fishes-an effect often suppressed. 
through natural selection, by secondary influences, but manifesting itself where these are not brought into play.

This species is in marked contrast with the darters, not only in the rapidity of its growth and the ultimate size attained, but in the form and size of the head, which in the darters is small and pointed, but in these fishes is unusually large, square and strong.

The principle of adaptation has here resulted in a different line of development. While the little Etheostomatidæ have become fitted to slip and pry about beneath the stones for their food, Hypentelium has acquired the power of rolling the stones before it. As it grows larger, it resorts, of course, to deeper water, but always prefers the rocky reaches of the stream. The moulding power of natural selection could scarcely have a better illustration than that afforded by the adaptive characters, both similar and dissimilar, of these two widely separated groups of fishes.

A single specimen of black sucker (Minytrema melanops) was too large properly to come within this group; but, although six inches long, most of its food was $\mathrm{Cy}$ clops (eighty per cent.). Other items were Alona, Difflugia, Closterium and very young Unios.

Four chub-suckers (Erimyzon sucetta), two of which were three-fourths of an inch, and two an inch and a quarter long, differed greatly in food from the foregoing. The two smaller specimens, from Long L., near Pekin, taken June 2, 1880, had eaten only Cladocera, with a trace of water mites. Chydorus was the principal element of their food (eighty per cent.), but Pleuroxus, Alona and Scapholeberis mucronata were also present. In the two larger specimens, locality and date unknown, a surprising number and variety of the minutest animal and vegetable forms were found. Squamella, Anuræa of several species, Rotifer vulgaris and other Rotifera; Difflugia and Arcella* among the Protozoa; Chroöcoceus, Closte-

* Slides of the food of this genus and Myxostoma were submitted to Dr. Jos. Leidy, of Philadelphia, and Prof. W. S. Barnard, of Cornell University, N. Y., and these gentlemen kindly sent me the following names of Rhizopoda as occurring therein: From Prof. Barnard, Diffugia acuminata, pyriformis, constricta and globosa; from Dr. Leidy, D. pyriformis, acuminata, globulosa, lobostoma and Arcella vulgaris and discoides 
rium, Cosmarium, Staurastrum and various diatoms among the Algæ, were the principal genera. A minute Agrion larvæ, a very young Amphipod, and larval Copepoda (nauplii), were the only other kinds recognized. It was obviously impossible to make any estimate of the ratios of such minute and varied objects occurring in such great quantity, and I have contented myself with a simple enumeration.

A specimen three inches long, from Peoria Lake, in October, had eaten only Copepoda (Canthocamptus) with a trace of Chironomus larvæ.

Ten specimens of red-horse (Myxostoma), varying in length from an inch to two and three-fourths, taken in July and August, from the Fox and Illinois rivers and from Mackinaw Cr., show no important differences of food.

In the smaller specimens, taken from the Fox and Illinois, Entomostraca, especially Cyprids, were relatively more important, sometimes constituting nearly the whole food; but no attempt was made to fix precise ratios. In the four larger specimens from Woodford Co., tests of Difflugia were estimated to form eighty-five per cent. of the contents of the intestines. These specimens were taken one at a time, several miles apart, along a rocky part of the stream. Besides the species of Difflugia and Arcella given in the foot note, various desmids and diatoms were abundant, with filamentous Algæ, rotifers (Squamella and Rotifer vulgaris), Cyclops, Alona, Pleuroxus and water mites, Chironomus and other Diptera larvæ, some indeterminable vegetable matter and a single Thrips (Hemiptera). The small percentage of Chironomus larvæ shows that this species has not the habit of the stone-roller.

Two specimens of the common sucker (Castostomus commersonii), six inches and six and three-fourths in length, taken from Mackinaw Cr., in August and June, had eaten food so similar to that of the preceding genus that detailed description is unnecessary.

Two specimens of the commonest buffalo-fish (Ichthyobus), seven-eighths of an inch long, had eaten most freely 
of unicellular Algæ (sixty-three per cent.), of which only Protococcus and Closterium were recognized. Specimens of Anuræa were reckoned at twenty-seven per cent., and the remainder of the food consisted of Copepoda and Cladocera. These specimens were taken from the Illinois R., in early June.

Four carp-suckers (Carpiodes), seven-eighths inch to two inches long, taken from the Illinois and from Clear L., in Kentucky, had fed like the preceding genus, except that the Entomostraca were in larger quantity (fortyeight per cent.), and included a number of Ostracoda, while the rotifers were comparatively few. The Daphniidæ of the Illinois R. specimens were nearly all $S c a p h$ oleberis mucronata. Canthocamptus in trivial numbers was also found in a single specimen.

Reviewing the food of these thirty young suckers, we see that they differ from the other families studied in the larger food-resources open to them; for, while the structure of their mouths does not prohibit their taking Entomostraca, it enables them to draw upon the multitudes of minute organisms found upon the bottom. Evidently they have no means of selecting such microscopie structures from the mud in which these most frequently rest, and considerable quantities of dirt are consequently often found in the intestines; but from the "richness" of the contents I infer that they doubtless have the power of distinguishing mud containing a large percentage of organic matter from relatively barren portions.

\section{SiLURID皮.}

Numerous specimens of the young of this family show that, notwithstanding its many peculiarities of structure and habit, it is no exception to the general rule respecting the food of the young. The smallest of these specimens were from a little school of minute fry, taken in June from the friendly protection of an old oyster-can in the Illinois R. These little creatures were colorless and seemingly almost helpless, and only three-eighths of an inch in length. They had already begun to eat, however, and their stomachs were well filled with Cyclops and a 
few Daphnids and Chironomus larvæ. These were certainly Amiurus, but it was of course impossible to tell the species.

Other specimens of this genus, making thirteen in all, none longer than an inch and five-eighths, were obtained from various places on the Illinois, and from mud-holes in the Mississippi bottoms, in Union Co. These thirteen individuals were feeding almost wholly on Entomostraca and larvæ of Chironomus, the latter composing seventyfour per cent. and the former eighteen per cent. of their food. Twenty-two per cent. of Cladocera include Simocephalus americamus and S. vetulus, Ceriodaphnia and $M a$ crothrix laticornis, * Jur., a species not hitherto reported from this country. Among the Lynceidæ (ten per cent.) I recognized Chydorus, Pleuroxus dentatus, Alona and Eurycercus lamellatus, and among the Ostracoda a species of Candona answering precisely to the description of Candona bifasciata, Say. A few young Amphipoda and a few unknown insects' eggs account for the remainder of the food.

Six specimens of Noturus sialis, varying in length from seven-eighths of an inch to an inch and a quarter, differed from the foregoing in the much larger proportion of Chironomus larvæ (forty-one per cent.) and in the twenty-six per cent. of young Allorchestes dentataeaten by the larger specimens. These had also taken seven per cent. larvæ of Ephemeridæ. Those under an inch in length were peculiar only in the large ratio of Chironomus larvæ (sixty-five per cent.), a fact probably indicating that this species seeks its food chiefly on the muddy bottoms.

No specimens of the other genera of catfishes were taken small enough to show their earliest food, but so far as can be judged from the food of four specimens of Ictalurus, from two and a half to three and a half inches long, the other genera will not be found to differ especially from the foregoing.

* Possibly this is not the species cited, but a careful comparison with the description and figures in Lilljeborg's "Crustacea ex Ordinibus Tribus." etc., failed to show any difference. 


\section{Амiгdж.}

A single dog-fish (Amia), one and three-fourths inches long, taken in June, had eaten seventy per cent. of Entomostraca-about equally Copepoda and Cladocera-and two per cent. of larvæ and pupæ of Chironomus. A few young Allorchestes and some Corixas complete the brief list.

Several specimens of Amia under one inch in length, whose anatomy I studied three years ago, I remember to have had their intestines packed with Entomostraca.

\section{LEPIDOSTEID $\&$.}

Here also I shall have to content myself with such hints of the food of the young as are given by two or three specimens, as the youngest are not yet common enough in our collections to supply more material for a study of their food. One of the two smallest gars examined, an inch and a fourth in length, taken in June, near Peoria, had filled itself with Scapholeberis mucronata, and the other had taken only a minute fish. A specimen two inches long and only an eighth of an inch in depth, furnished a striking illustration of the voracity of this terror of our streams, as its stomach contained sixteen minute Cyprinoids.

\section{Summary.}

A sufficient recapitulation of the foregoing data is afforded by the appended table of the food of the different genera. It may be worth while to say that all the material upon which the foregoing statements rest, as well as all that used in the preceding paper, has been carefully preserved, and may be seen at any time by those interested, at the State Laboratory of Natural History.

The general conclusion from these observations is the supreme importance of Entomostraca and the minute aquatic larvæ of Diptera as food for nearly or quite al of our fresh-water fishes-a conclusion that gives these trivial and neglected creatures, of whose very existence the majority of the people are searcely aware, a prominent place among the most valuable animals of the State, 
for without them all our waters would be virtually depopulated. Other facts of eminent interest thus brought to view are the magnitude and intensity of the competition for food among the young of all orders of fishes, where a stream is fully stocked, and the injurious character of such a species as the shovel-fish, which feeds on Entomostraca throughout its life. It is probable that all fishes which are not especially adapted to the food requirements of the more valuable fishes, are hurtful to them, because they limit the food available for the young. The sunfishes, whose shape protects them from many enemies, and the catfishes, with their armor of poisoned spines, are instances in point. While their young compete with the young bass and wall-eyed pike for food, they do not furnish the latter any important food resource in later years. On the other hand, such species as the herbivorous minnows and the cylindrical suckers, which depend upon Entomostraca to a less extent when young, or take up other food at a relatively early period, are those which seem to promise best as food for the higher fishes.

It is a curious corollary from the above reasoning that a prolific species having an abundant food supply, and itself the most important food of predaceous fishes, may, by extraordinary multiplication, so diminish the food of the young of the latter as to cause, through its own abundance, a serious diminution of the numbers of the very species which prey upon it. To put this statement into more concrete form, it is not certain that the excessive increase of the gizzard-shad, for instance, would be a benefit to the black bass and pike-perch which feed so largely upon it. In fact, it is clear that the great overstocking of a stream with gizzard-shad would, by eventually reducing the supply of Entomostraca, cause a corresponding reduction in the numbers of all the species of that stream by starvation of the young; and this decimation, applying to all in the same ratio, would take effect upon the ordinary number of the other species, but upon the extraordinary number of the gizzard-shad-would reduce the other species below the usual limit, but might not even cut off the excess of the shad above that limit. Conse- 
quently, important as is the supply of food fishes for the predaceous species, it is not less important that the predaceous species should be supplied to eat up the food. Here, as elsewhere, only harm can come from an imperfect balance of the forces of organic nature, whether the excess be upon one side or the other.

In the effort to increase the valuable fishes of a lake or stream, it is not sufficient that the food of these species should be increased alone, but at the same time special measures must be taken to secure a corresponding multiplication of the predaceous fishes themselves, otherwise precisely the reverse result may be produced from that intended.

As a further illustration of some of the practical bearings of these facts. it may be noticed that the free access of fishes to the ponds, lakes and marshes connected with a sream is a matter of the highest importance. Running: water is relatively destitute of Entomostraca, and hence fishes denied access while breeding to slow or stagnant water in which Entomostraca abound, have no chance to multiply. The condition of fish life in the lower Fox R. will illustrate this point. This stream takes its rise in the numerous lakes of northwestern Illinois and southern Wisconsin, but in its lower course has few branches and no stagnant waters draining into it. Its own current is swift and much of its bed is rocky, while the vast expanse of water of which it forms the outlet prevents any great oscillations of its level with the consequent flooding of adjacent lands. This part of the stream is therefore peculiarly unfit for breeding purposes, and we should expect few fish to maintain themselves in it if denied access to the immense and teeming breeding grounds of the upper part of the river. Such access is effectually cut off by several dams, unprovided with fishways, which have been thrown across the stream. A fish which enters the river from above therefore cannot get back to breed-a fact which must unfavorably affect the number of fishes in both river and lakes, and is apparently one cause of an unusual scarcity of game fishes in that stream. 
Table of Food of Young Fishes.

\begin{tabular}{|c|c|c|c|c|c|c|c|c|c|}
\hline & 造 & $\begin{array}{l}\text { ป } \\
\text { 일 } \\
\text { ¿ }\end{array}$ & 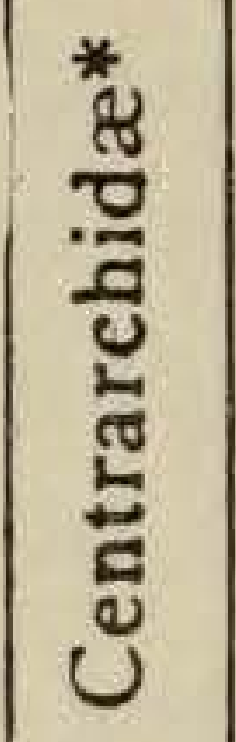 & 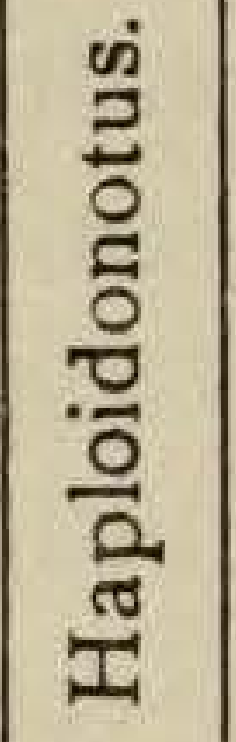 & $\begin{array}{l}\rtimes \\
\text { on } \\
\text { |c }\end{array}$ & 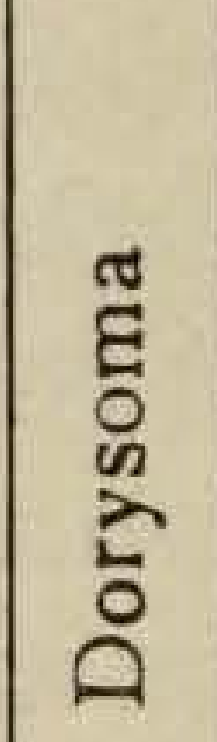 & 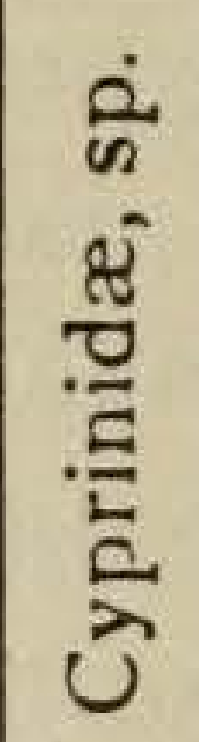 & 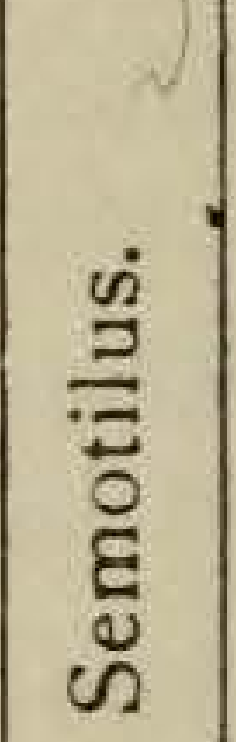 & $\frac{\frac{\dot{n}}{0}}{\frac{2}{0}}$ \\
\hline Number of specimens..... & 6 & 1 & 43 & I & I & 12 & I & 3 & 2 \\
\hline Size in inches & 193 & $11 / 4$ & $\begin{array}{c}5 / 8 @ \\
2\end{array}$ & $11 / 8$ & $11 / 4$ & $\begin{array}{r}1 / 2 @ \\
13 / 4 \\
\end{array}$ & $3 / 8$ & $\begin{array}{l}5 / 8 \\
\text { (a) } 1\end{array}$ & $11 \%$ \\
\hline KINDS OF FOOD. & \multicolumn{9}{|c|}{$\begin{array}{l}\text { Ratios in which each element of food } \\
\text { was found. }\end{array}$} \\
\hline I. FISHES.... & $\cdots$ & 50 & & & 40 & & & & \\
\hline $\begin{array}{l}\text { Dorysoma............. } \\
\text { II. Mollusks.... }\end{array}$ & & $\begin{array}{l}50 \\
\ldots\end{array}$ & 1 & & & & & & \\
\hline III. INSECTS............. & 08 & $\cdots$ & 28 & 100 & $\cdots$ & $\because \ldots$ & 75 & & \\
\hline 1. Diptera (larvæ)........... & 08 & $\cdots$ & 26 & 75 & $\cdots$ & 02 & 75 & & \\
\hline $\begin{array}{l}\text { Chironomus.............. } \\
\text { Corethra } . \ldots \ldots \ldots \ldots \ldots \ldots\end{array}$ & $\begin{array}{c}08 \\
\ldots \ldots\end{array} \mid$ & $\begin{array}{l}\cdots \\
\cdots\end{array}$ & 26 & 75 & $\begin{array}{l}\cdots \\
\cdots\end{array}$ & $\begin{array}{r}02 \\
+\end{array}$ & 75 & & $\cdots$ \\
\hline 2. Hemiptera (young).. & $\cdots$ & $\cdots$ & $\dddot{t}$ & & $\begin{array}{l}\cdots \\
\cdots\end{array}$ & ... & $\cdots$ & & \\
\hline Corixa....... & $\ldots$ & $\cdots$ & $t$ & $\ldots$ & .... & $\cdots$ & $\ldots$ & & $\cdots$ \\
\hline 3. Neuroptera (larvæ).. & $\ldots$ & ... & 02 & 25 & $\ldots$ & $\cdots$ & $\ldots$ & & \\
\hline $\begin{array}{l}\text { Ephemeridæ.......... } \\
\text { Palingenia ........ }\end{array}$ & $\ldots$ & $\cdots$ & $\cdots$ & $\begin{array}{l}25 \\
25\end{array}$ & $\cdots$ & $\cdots$ & $\cdots$ & & $\cdots$ \\
\hline IV. HYDRACHNID & & & $\cdots$ & 25 & $\ldots$ & $\cdots$ & & & . \\
\hline V. $\mathrm{C}_{\mathrm{R}}$ & 92 & 50 & 72 & $\cdots$ & 60 & 90 & 25 & 07 & 100 \\
\hline Amphipoda (young) & $\ldots$ & $\ldots$ & $\mathrm{O} 2$ & 1... & 20 & ... & & & \\
\hline Entomostraca....... & 92 & 50 & 70 & $\ldots$ & 40 & 90 & 25 & 07 & 100 \\
\hline Cladocera...... & $5^{2}$ & 40 & 42 & $\ldots$. & 40 & 42 & 25 & $\cdots$ & 100 \\
\hline Sidid & $\cdots$ & $\cdots$ & 02 & $\cdots$ & $\cdots$ & $\cdots$ & $\cdots$ & $\cdots$ & \\
\hline Daphniic & $5^{c}$ & . & 36 & $\cdots \cdots$ & 20 & 34 & 25 & & I0 \\
\hline Lync & 02 & $\ldots$ & 04 & $\ldots \ldots$ & 20 & 04 & & & \\
\hline Lept & ... & $\cdots$ & $\cdots$ & $|\cdots \cdot|$ & $\cdots$ & $\mathrm{O} 2$ & & $\cdots$ & $\cdots$ \\
\hline Ostracoda........... & & $\cdots$ & 09 & $\ldots$ & & $t_{0}^{\dagger}$ & $\cdots$ & & $\cdots$ \\
\hline $\begin{array}{l}\text { Copepoda } \ldots \ldots \\
\text { VI. ALGE } \ldots \ldots \ldots\end{array}$ & 40 & 10. & $\begin{array}{l}\text { I9 } \\
\ldots\end{array}$ & $\begin{array}{l}\cdots \\
\cdots\end{array}$ & & $\begin{array}{l}48 \\
08\end{array}$ & & $\begin{array}{l}07 \\
93\end{array}$ & \\
\hline
\end{tabular}

* For detailed tables of the food of the young of this family see the preceding paper on the food of the Acanthopteri. 
Table of Food of Young Fishes-Continued.

\begin{tabular}{l|c|c|c|c|c|c|c|c|c|c}
\hline \hline & & & & & & & & & \\
\\
\end{tabular}

